\title{
ORGANIC FARMING FOR CROP IMPROVEMENT AND SUSTAINABLE AGRICULTURE IN THE ERA OF CLIMATE CHANGE
}

\author{
${ }^{1}$ Rajib Roychowdhury, ${ }^{2}$ Upasana Banerjee, ${ }^{3}$ Svetla Sofkova and ${ }^{4}$ Jagatpati Tah \\ ${ }^{1}$ Department of Biotechnology, Visva-Bharati, Santiniketan-731235, West Bengal, India \\ ${ }^{2}$ Department of Botany, Visva-Bharati, Santiniketan-731235, West Bengal, India \\ 3“Maritsa" Vegetable Crops Research Institute, 32 Brezovsko shosse St., 4003 Plovdiv, Bulgaria \\ ${ }^{4}$ Department of Botany (UGC-CAS), The University of Burdwan, Burdwan-713104, West Bengal, India
}

Received 2013-06-17, Revised 2013-06-26; Accepted 2013-07-05

\begin{abstract}
Sustainable development has caught the imagination and action of the world for more than a decade. Sustainable agriculture is necessary to attain the goal of sustainable development. According to the Food and Agriculture Organization (FAO), sustainable agriculture is the successful management of resources to satisfy the changing human needs while maintaining or enhancing the quality of environment and conserving natural resources. All definitions of sustainable agriculture lay great emphasis on maintaining an agricultural growth rate, which can meet the demand for food of all living beings without draining the basic resources towards crop improvement. Organic farming is one of the several approaches found to meet the objectives of sustainable agriculture. Most of the techniques used in organic farming like intercropping, mulching and integration of crops and livestock are not alien to agriculture systems including the traditional agricultural practices. However, organic farming is based on various laws and certification programmes, which prohibit the use of almost all synthetic inputs and the central theme of this method is the health of soil. The adverse effects of modern agricultural practices on the farm and also on the health of living beings and thus on the environment has been well documented all over the world. Application of technology, particularly the use of chemical fertilizers and pesticides all around us has persuaded people to think aloud. As a result of global climatic changes, their negative effects on the environment are manifested through soil erosion, water shortages, salination, soil contamination, genetic erosion, Organic farming is one of the widely used methods, which is thought as the best alternative to avoid the ill effects of chemical farming. It also has far more advantages over the conventional and other modern agricultural practices that are available today.
\end{abstract}

Keywords: Climate Change, Crop Improvement, Organic Farming, Production and Yield, Sustainable Agriculture

\section{INTRODUCTION}

There are several definitions of organic farming but the most coherent and stringy definition is given by the US Department of Agriculture (USDA). According to it, organic farming is defined as a system that is designed and maintained to produce agricultural products by the use of methods and substances that maintain the integrity of organic agricultural products until they reach to the consumers. This is accomplished by using substances, to fulfill any specific fluctuation within the system so as to maintain long term soil biological activity, ensure effective peak management, recycle wastes to return nutrients to the land, provide attentive care for farm animals and handle the agricultural products without the use of extraneous synthetic additives or processing in accordance with the act and the regulations in this part. The origin of organic farming goes back, in its recent history, to 1940s.

Corresponding Author: Rajib Roychowdhury, Department of Biotechnology, Visva-Bharati, Santiniketan-731235, West Bengal, India 


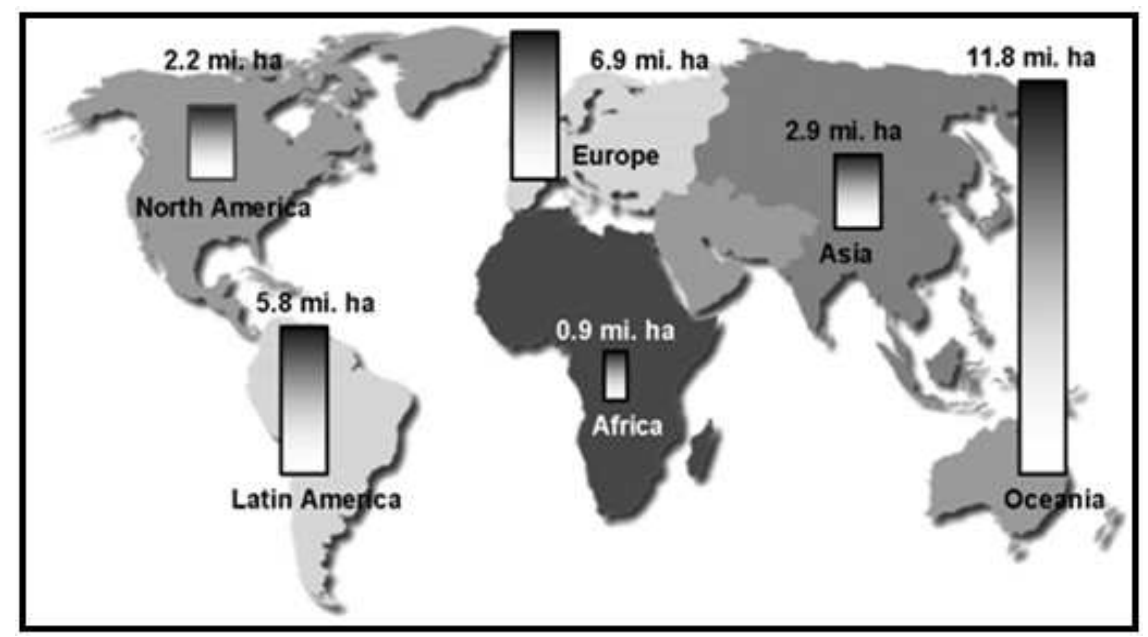

Fig. 1. Area under organic agriculture worldwide (Source: www.organicfarming.com.html)

Table 1. Percentage of area under organic farming in the total cultivated area of different countries of the world

\begin{tabular}{ll}
\hline Country & $\begin{array}{l}\text { Percentage of area } \\
\text { under organic farming }\end{array}$ \\
\hline USA & 0.23 \\
UK & 4.22 \\
Germany & 4.10 \\
Argentina & 1.70 \\
Austria & 8.40 \\
Australia & 2.20 \\
Japan & 0.10 \\
Switzerland & 7.94 \\
South Africa & 0.05 \\
Italy & 3.70 \\
India & 0.03 \\
Pakistan & 0.08 \\
Srilanka & 0.05 \\
\hline
\end{tabular}

During this period, the path breaking literature on the subject published by J. I. Rodale in the United States, Lady Balfour in England and Sir Albert Howard in 1940 in India contributed to the cause of organic farming.

Organic farming seems to be more appropriate, as it considers the most important aspects like sustainability of natural resources and environmental safety. It is a production system which favour maximum use of organic materials (like crop residue, animal residue, legumes, on and off farm wastages, growth regulators, bio-pesticides) and discourages the use of synthetically produced agro-inputs for maintaining soil productivity, fertility and pest management under conditions of sustainable natural resources and healthy environment. In this study, a review of literatures on organic farming is focused as an alternative for sustainable crop production.

\subsection{Status of Organic Farming-A World Scenario}

Organic agriculture is developing rapidly and today at least 141 countries produce organic food commercially. As per the estimates of the year 2007, about 32.2 million hectares (Mha) of organic food was produced globally, managed by more than 1.2 million producers, including smallholders. In addition to agricultural land, there is 0.4 Mha of certified organic aquaculture. About $65 \%$ of the developing countries are involved in organic farming. The countries with the largest areas of organically managed agricultural land are: Oceania, Europe and Latin America, Australia, Argentina and Brazil (Fig. 1). Almost 11 Mha i.e., about one-third of the world's organically managed land is located in the developing countries (Reddy, 2010). Most of this land is in Latin American countries, while Asia and Africa take the second and third places, respectively. On a global level, in the year 2008, organic land area increased by almost 1.5 Mha compared to the data for the year 2006. About 28\% (or 1.4 Mha) more land under organic management was reported for Latin America (including 0.9 Mha of inconversion land in Brazil for which no data was available previously). Organically managed land increased by 0.33 Mha $(+4 \%)$ in Europe and by 0.18 Mha $(+27 \%)$ in Africa (Willer and Klicher, 2009). Austria has the highest percentage $(8.4 \%)$ of area under organic farming, followed by Switzerland, UK and Germany. In India, only $0.03 \%$ of the area is under organic farming, though there is huge scope for bringing more land under organic farming. Area percentage under organic farming of different countries in the world is represented in Table 1. 


\subsection{Principles of Organic Farming}

The main principles of organic farming are as follows (Chandrashekar, 2010):

- To work within a closed system and draw upon local resources as much as possible

- To maintain long-term fertility of soils

- To avoid all forms of pollution that may result from agricultural techniques

- To produce foodstuffs in sufficient quantity and having high nutritional quality

- To minimize the use of fossil energy in agricultural practices

- To give livestock conditions of life that confirm to their physiological needs

- To make it possible for agricultural producers to earn a living through their work and develop their potentialities as human being

The main pillars of organic farming are:

- Organic threshold standards

- Reliable mechanisms regarding certification and regulatory affairs

- Technology packages

- Efficient and feasible market network

\section{MAJOR PILLARS OF ORGANIC FARMING BASED AGRICULTURE}

There are four major pillars of organic agriculture and they are as follows (IFOAM, 2010):

\subsection{Principle of Health}

Organic agriculture should sustain and enhance the health of soil, plant, animal, human and planet as one and indivisible. This principle points out that the health of individuals and communities cannot be separated from the health of ecosystems-healthy soils produce healthy crops that foster the health of animals and people. Health is the wholeness and integrity of living systems. It is not simply the absence of illness, but also the maintenance of physical, mental, social and ecological well-being. Immunity, resilience and regeneration are the key characteristics of health. The role of organic agriculture, whether in farming, processing, distribution, or consumption, is to sustain and enhance the health of ecosystems from the smallest organisms in the soil to the human beings. In particular, organic agriculture is intended to produce high quality nutritious food that contributes to preventive health care and well-being. In view of this it should avoid the use of fertilizers, pesticides, animal drugs and food additives that may cause adverse health effects.

\subsection{Principle of Ecology}

Organic agriculture should be based on living ecological systems and cycles, work, emulate and help to sustain them. This principle roots organic agriculture within living ecological systems. It states that production is to be based on ecological processes and recycling. Nourishment and well-being are achieved through the ecology of the specific production environment. For example, in case of crops this is the living soil; for animals it is the farm ecosystem; for fish and marine organisms it is the aquatic environment. Organic farming, pastoral and wild harvest systems should fit the cycles and ecological balances in nature. These cycles are universal but their operation is site-specific. Organic management must be adapted to local conditions, ecology, culture and scale. Inputs should be reduced by reuse, recycling and efficient management of materials and energy in order to maintain and improve environmental quality and conserve resources. Organic agriculture should attain ecological balance through the design of farming systems, establishment of habitats and maintenance of genetic and agricultural diversity. Those who produce, process, trade, or consume organic products should protect and benefit the common environment including landscapes, climate, habitats, biodiversity, air and water.

\subsection{Principle of Fairness}

Organic agriculture should be built on relationships that ensure fairness with regard to the common environment and life opportunities. Fairness is characterized by equity, respect, justice and stewardship of the shared world, both among people and in their relations to other living beings. This principle emphasizes that those involved in organic agriculture should conduct human relationships in a manner that ensures fairness at all levels and to all parties-farmers, workers, processors, distributors, traders and consumers. Organic agriculture aims at providing a good quality of life to everyone involved with it and contribute to food sovereignty and reduction of poverty. It aims to produce a sufficient supply of good quality food and other products. This principle insists that animals should be provided with the conditions and opportunities of life that accord with their physiology, natural behavior and well-being. Natural environmental 
resources that are used for production and consumption should be managed in a way that is socially and ecologically just and should be held in trust for future generations. Fairness requires systems of production, distribution and trade that are open and equitable and account for real environmental and social costs.

\subsection{Principle of Care}

Organic agriculture should be managed in a precautionary and responsible manner to protect the health and well-being of current and future generations as well as the environment. Organic agriculture is a living and dynamic system that responds to internal and external demands and conditions. Practitioners of organic agriculture can enhance efficiency and increase productivity, but this should not be at the risk of jeopardizing health and well-being. Consequently, new technologies need to be assessed and existing methods should be reviewed. The incomplete understanding of ecosystems and agriculture should be taken care of. This principle states that precaution and responsibility are the key concerns in management, development and technology choices in organic agriculture. Science is necessary to ensure that organic agriculture is healthy, safe and ecologically sound. Along with scientific knowledge practical experience, accumulated wisdom, traditional and indigenous knowledge also offer valid solutions, which are tested by time. Organic agriculture should prevent significant risks by adopting appropriate technologies and rejecting unpredictable ones, such as genetic engineering. Decisions should reflect the values and needs of all who might be affected, through transparent and participatory processes.

\section{COMPONENTS OF ORGANIC FARMING}

There are assumptions throughout the organic literature of differences between organic and conventional systems with respect to their effects on soil physical properties, soil insect fauna and nutrient flow within the soil, crop health and nutritional value of the harvested crop. Different components of organic farming are as follows.

\subsection{Crop and Soil Management}

Organic farming system encourages the use of rotations and measures to maintain soil fertility. Carefully managed soil with a high production of humus offer essential advantages with respect to the water retention capacity, ion exchange, soil erosion and animal life in the soil. Green manuring and inter-cropping of legumes is another important aspect for biological farming systems. It not only helps in controlling weeds but also in improving its chemical and physical properties by reducing the leaching of nutrients and reducing soil erosion. A green cover at most throughout the year is one of the main goals of such farming methods. Depending on the green manure mixture or the legumes used for under sowing, there may be an increase in soil organic matter, soil $\mathrm{N}_{2}$ as well as increase in other nutrient level. Researches have shown that yields of maize improve in rotation system with soybeans, often by as much as $80 \%$ (Carscy et al., 1997).

\subsection{On-farm Waste Recycling}

Increase in price of chemical fertilizers has enabled organic wastes to regain an important role in the fertilizer practices on the farm. Good manure management means improved fertilizers value of manure and slurry and less nutrient losses. Composting of all organic wastes in general and Farm Yard Manure (FYM) or feedlot manure in particular is important in organic farming.

\subsection{Non-chemical Weed Management}

Weed management is one of the main concerns in organic agriculture. Generally, all aspects of arable crop production play an important role in a system approaching to problems. The elements to consider in preventing weed problems are crop rotation, green manuring, manure management and tillage. Mulching on a large scale by using manure spreaders may also be useful in weed control.

\subsection{Domestic and Industrial Waste Recycling}

Use of sewage and sludge for crop production can form an important component of organic farming if treatment and application methods are improved further.

\subsection{Energy Use}

The energy required for production, measured per rupees of produce for organic farms is only one third compared to their conventional counterparts. Because Nfertilizer and pesticides are not used by biological farmers, the comparison of total energy input/ha with total energy output favors biological farming systems.

\subsection{Food Quality}

Food quality is one of the main issues, which concerns both scientists and consumers. Nitrates in water and farm produce, desirable components, pesticides 
residues, keeping quality and physiological imbalances are some of the important aspects of food quality.

\subsection{Ecological Agriculture}

The growing concern about environmental degradation, dwindling natural resources and urgency to meet the food needs of the increasing population are compelling farm scientist and policy makers to seriously examine alternatives to chemical agriculture. As reported by (Venkataramani, 1995), case studies show that when chemical farm incurred about 11.250 towards the cost of cultivation of rice. An organic farm spend rupees 10,590 to produce $5625 \mathrm{~kg}$ paddy and 8 tons of straw/ha. The net returns from the ecological farming system at the current cost of rupees $3.34 \mathrm{~kg}^{-1}$ paddy is rupees $8,197.50$. In chemical farming, the net profit is rupees 7500. If one gets a premium price for the poison force of organically grown rice, the economic returns from the ecological farming system will be highly encouraging.

\subsection{Integrated Intensive Farming System (IIFS)}

IIFS involves intensive use of farm resources. To be ecologically sustainable, such intensification should be based on techniques which are knowledge intensive and which replace to the extent possible, market purchased chemical inputs with farm grown biological inputs (Venkataramani, 1995).

\section{ORGANIC FARMING AND SUSTAINABLE AGRICULTURAL DEVELOPMENT}

The extensive use of agro chemicals in modern farming by the developed and under developed countries, cause various adverse effect on soil, water, food and atmospheric environment which are reviewed below.

\subsection{Fertilizer Pollution}

In the developed countries, there has been intensive use of fertilizers since the last four decades. The polluting effects of fertilizers are being observed now; similar problems in the developing countries should be expected in the near future. Some important problems associated with fertilizers pollution are summarized below.

\subsubsection{Nitrate Pollution}

Application of $\mathrm{N}_{2}$ fertilizers such as urea and ammonium sulphate to soils produces acid by two processes. Firstly, the natural process of oxidation of ammonium ions to nitrate ions release acid. Part of acid produced is neutralized by alkaline ions released by plants during the subsequent uptake of the nitrate ions. Secondly, since nitrate ions are not strongly absorbed by the soil they are liable to leach or move down through the soil. The negatively charged nitrate ions carry positively charged basic cataions such as $\mathrm{Ca}, \mathrm{K}, \mathrm{Mg}$ and $\mathrm{Na}$ in order to maintain the electric charge on the soil particles. A high nitrate concentration indicates the likely presence of harmful bacteria as well. In condition, to high enrichment, $\mathrm{NO}_{3}$ may produce a state known as methamoglobinemia (blue babies) which generally affect the infants under six months of age. Repeated heavy dose of nitrate on ingestion may likely cause carcinogenic diseases. Consumption of high dose of $\mathrm{NO}_{3}$ may develop symptoms of dizziness, abdominal cramps, vomiting, weakness, convulsion, mental impairment and even nitrosamine which causes stomach cancer. Apart from this, overuse of $\mathrm{N}_{2}$ fertilizers leads to swindling of earthworms from the particular area. Earthworms have always been considered a farmer's friend and their absence means loss to the soil fertility.

\subsubsection{Accumulation of Heavy Metals}

Contamination of soil by heavy metal through fertilizers such as cadmium from phosphate fertilizers is catching the increasing attention of environmentalists (Kostial, 1977). Health hazards associated with heavy metals entering the food chain through soil is demanding attention. Fertilizers contain heavy metals as impurities. The application of rock phosphate or its produce to soil always implies the addition of significant amount of lead and cadmium into the soil. Analysis of several commercial fertilizers commonly used revealed that a combination of low analysis and straight fertilizers can add more lead and cadmium to soil than high analysis and mixed fertilizers (Arora et al., 1995).

\subsubsection{Eutrophication of Water}

It is the process of enrichment of surface water bodies like lakes, reservoirs and dreams with nutrients. Nutrient enrichment of water bodies results in intense proliferation and accumulation of algae and higher aquatic plants in excessive quantities which can result in detrimental changes in water quality and can significantly interfere with the use of water resources. The excessive accumulation of dissolved nutrients such as phosphorus, nitrogen, silicon and other element in water leads to an excess production of algal biomass. This requires a corresponding increase in supply of oxygen for decomposition of organic materials when the algae and their remnants sink to bottom, this leads to reduced $\mathrm{O}_{2}$ content and eventually anaerobic condition may prevail. This may cause severe eutrophication and 
lead to serious loss of marine life, blockage of aquatic passages and a major reduction in real estate value of the affected areas. The normal $\mathrm{N}$ : $\mathrm{P}$ ratio in water is around 20:1. Algal growth increases when this ratio drops to around 7:1 (Asmed, 1993). In the developed countries like USA, more than $50 \%$ of the community and rural wells are contaminated with nitrate nitrogen $\left(\mathrm{NO}_{3} \mathrm{~N}\right)$ due to heavy use of fertilizers. The contamination has exceeded the standard (10 $\mathrm{mg} \mathrm{NO} /$ lit.) of drinking water by $2 \%$ (Dahama, 2009).

\subsubsection{Stratospheric Changes}

Many research studies involved in the atmosphere may increase the rate of reaction in the stratosphere that cause the distraction of ozone layer. The stratosphere ozone layer shields the biosphere from the harmful ultraviolet radiations and also influences the earth's temperature (Dahama, 2009). Nitrogen loss to the atmosphere through denitrification may contribute to "green-house gases" in the atmosphere thereby exacerbating the problems of breaking down of the ozone layer. Nitrogen losses can be particularly high from intensively cultivated and fertilized land whether the fertilizer form is organic or inorganic.

\subsection{Pesticide Pollution}

The use of different types of poisonous substances as pesticides, contribute towards imbalances in the ecosystem and polluting the environment. Pesticides are extremely used nowadays to control various pests which are harmful to the crops raised by man for food, feed and fiber production. However, most of the chlorinated pesticides are non-biodegradable and leave residue which are detrimental to human beings, animals and the environment.

\subsubsection{Insecticide Pollution}

The presence of residues of insecticides in food commodities and other components of the environment is a matter of serious concern. Even small quantities of the residues ingested daily along with food can build up to high levels of body fat (Dhaliwal and Koul, 2010). Therefore there is a content fear that society is being slowly poisoned by the intake of food contaminated with pesticide residues. During the 1900's, there was little information available on the bad impose of pesticide on soil and water quality. Organochlorine insecticides such as chlorine, dieldrin, DDT and heptachlor were widely used in agriculture to control insect/pests in different countries. Since 1960's, the organochlorine use was progressively restricted and is finally banded now.
Nevertheless, their residues are still found in soil and continue to cause problems of food and food contamination. The metabolite of DDT still occurs in the top $150 \mathrm{~mm}$ of the soil profile of Canterbury region in Switzerland (Scaife and Turner, 1983).

\subsubsection{Herbicide Pollution}

The use of chemicals for controlling weeds started with the introduction of 2,4-D in 1940's. The usage of herbicide is higher than any agro-chemicals. Farming has now realized the importance of herbicide usage for harvesting higher crop yields.

\subsubsection{Negative Effect on Soil Ecosystem}

Herbicide plays an important role in the disturbance of soil ecosystem where soil micro-flora and fauna lies in the breaking down of organic matter, incorporating it into the soil and releasing nutrients for plant growth. The herbicide can have direct effect upon decomposing micro-organisms, rhizosphere micro-organisms, root pathogens and disease antagonists such as parasites and predators as well as organisms pathogenic to invertebrates. Herbicides are designed specifically to minimize plant diversity by controlling weeds thus promoting monoculture. So, they can also indirectly decrease populations and diversity of related soil organisms and lessen the natural input of organic matter into soil as well as have direct effect on soil organism. This may in turn increase the need for inorganic fertilizers and pesticides and magnify the inputs of agrochemicals in soil ecosystem.

\subsubsection{Bad Effect in Farmer's Health}

The increased uses of herbicides in recent years have caused more concern due to their effect on farmer's health. While herbicide technology has made remarkable progress in terms of developing sage herbicides that are less toxic to human beings, many farmers still suffer from chemical poisoning after applying herbicides. The extensive use of pesticides possesses a more direct problem on farm workers. Epistemologies data shows that workers who handle pesticides more than 20 days a year have an increased risk of developing certain type of cancer (Dahama, 2009).

\subsubsection{Soil, Water and Environment Effect}

We can probably assume that herbicides applied over many years are always going to have some adverse impact on the environment. They not only affect many species of plants and animals in and around farmland but 
also cause pollution of underground as well as surface water. New ecotypes of weed which are resistant to herbicides have developed. Some species even have multiple resistant to all possible options and choosing those that maximize profit is currently accepted as a key strategy in modern pest control.

\section{MICROBIAL FERTILIZERS/ BIOFERTILIZERS AS A NON- TRADITIONAL ADDITIVE FOR ORGANIC FARMING}

Bio-fertilizers are the biological active product called microbial inoculates containing active strain of selective micro-organisms like bacteria, fungi, algae or in combination. The bio-fertilizers containing biological nitrogen fixing organisms are of upmost importance in agriculture in the view of the following advantages.

\subsection{Advantages of Bio-Fertilizers}

- They enhance bio-mass production and grain yield by $10-20 \%$

- They are cheap and can help to reduce the consumption of chemical fertilizer

- They make nitrogen available directly to the plant

- They solubilize phosphorus and increase phosphorus uptake to the plants

- They enhance plant growth due to release of hormones, vitamins, auxins

- They improve the soil properties and sustain soil fertility

- They control and suppress soil borne diseases

- They are suitable in organic farming

\subsection{Organisms Used as Bio-Fertilizers}

\subsubsection{Rhizobium}

Rhizobium is well known for its capacity to establish a symbiosis with leguminous plants. They inhibit root nodules, where reduce atmospheric nitrogen and make it available to the plant. Biological nitrogen fixation is an important component of sustainable agriculture and rhizobial inoculants have been the most widely used bio-fertilizers. Furthermore, rhizobia are frequent rhizosphere colonizers of a wide range of plants and may also inhibit non-leguminous plants endophytically. In these rhizospheric and endophytic habitatas, they may exhibit several plant growthpromoting effects, such as hormone production, phosphate solubilization and the suppression of pathogens (Sessitsch et al., 2002). The Joint FAO/IAEA programme of co-ordinated research showed that inoculation with a suitable strain of rhizobium at sowing was the single most useful agronomic practice in ensuring maximum legume yield. The rhizobium-legume mutually beneficially (symbiotic) association can fix up to $100-300 \mathrm{~kg} \mathrm{~N} / \mathrm{ha}$ in one crop season and in certain situation can leave behind substantial nitrogen for following crops (Dahama, 2009). Inoculation of seed is also inexpensive. On the other hand, the formulation, production and delivery of viable inocula for a particular crop at the time of sowing are exacting (Stephens and Rask, 2000). Once applied to the soil, rhizobium inoculants remain relatively immobile and, as a consequence, application on or with the seed at sowing results predominantly in crown and tap root nodulation. Mixing rhizobia with the soil leads to more profuse nodulation on most parts of the root system, but such agronomic practice that spread the inoculum more evenly in the soil are less used. Therefore criteria sought in inoculants include survival and mobility in soil, colonization of the rhizosphere, the ability to compete for rapid infection of the host root system, as well as to provide sufficient effective nodules to realize the $\mathrm{N}_{2}$ fixing potential of the legume. The concept of specific strain/host genotype combination for optimizing $\mathrm{N}_{2}$ fixation has also been extended (Hardarson and Atkins, 2003).

\subsubsection{Azotobacter}

The beneficial effects of Azotobacter bio-fertilizers on cereals, millets, vegetables, cotton and sugarcane under both irrigated and rainfed field condition have been subestimated and documented (Pandey and Sharma, 1989). Application of Azotobacter has been found to increase the yield of wheat, rice, maize, pearl millet and sorghum by $0-30 \%$ over control. Apart from N, these organisms are also capable of producing antibacterial and anti-fungal compounds, hormones and siderophores (Dahama, 2009). Research done in Nepal shows that the amount of nitrogen to be applied to wheat can be cut down to $15 \%$ if inoculation with effective strain of Azotobacter is practiced (Karki and Baral, 1977).

\subsubsection{Azospirillum}

A very important bacterium discovered by Brazilian Scientists in 1970's. Its application increase grain productivity of cereals by $5-20 \%$ and of fodders by over $50 \%$. The Azospirillum form associative symbiosis with many plants particularly with those having the $\mathrm{C}_{4}$ dicarboxyliac path way of photosynthesis (Hatch and Slack pathway), because they grow and fix nitrogen on 
salts of organic acids such as malic, aspartic acid (Sharma, 2004). Thus it is mainly recommended for maize, barley, sugarcane, sorghum, pearl millet, forage crops.

\subsubsection{Blue Green Algae (BGA)}

The utilization of BGA as a bio-fertilizer for rice is very promising, so also referred as 'paddy organisms'. N is the key input required in large quantities for low land rice production. Soil $\mathrm{N}$ and $\mathrm{BNF}$ by associated organisms are major sources of $\mathrm{N}$ for low land rice. The $50-60 \% \mathrm{~N}$ requirement is met through the combination of mineralization of soil organic $\mathrm{N}$ and BNF by free living and rice plant associated bacteria (Roger and Ladha, 1992). To achieve food security through sustainable agriculture, the requirement for fixed nitrogen must be increasingly met by BNF rather than by industrial nitrogen fixation. Most $\mathrm{N}$ fixing $\mathrm{BGA}$ are filamentous, consisting of chain of vegetative cells including specialized cells called heterocyst which function as micro nodule for synthesis and $\mathrm{N}$ fixing machinery. BGA forms symbiotic association capable of fixing nitrogen with fungi, liverworts, ferns and flowering plants, but the most common symbiotic association has been found between a free floating aquatic fern, the Azolla and Anabaena Azollae (BGA) (Mahdi et al., 2010). BGA have contributed greatly to the enrichment maintenance of soil fertility in rice fields. On farm level, the algae can contribute to about $25-30 \mathrm{~kg}$ N/ha. Recent researches have shown that algae also help to reduce soil alkalinity and this opens up possibilities for bio-reclamation of such inhabitable environment.

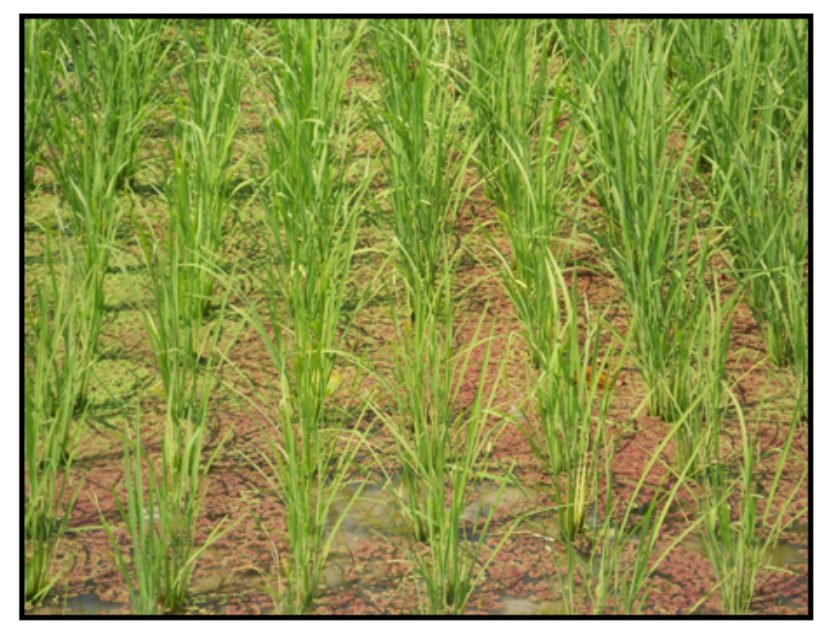

Fig. 2. Organic agriculture based traditional rice cultivation using Azolla as a bio-fertilizer

\subsubsection{Azolla}

A small floating water fern, Azolla is commonly seen in low land fields and shallow fresh water bodies. This fern harbors a blue green algae Anabaena azollae. This Azolla-Anabaena symbiotic association is a live floating nitrogen factory using energy from photosynthesis to fix atmospheric nitrogen amounting to $100-150 \mathrm{~kg} \mathrm{~N} / \mathrm{ha}$ nitrogen from about 40-60 tons of biomass (Singh, 2003). Patel et al. (1982) have reported while summarizing the responses of rice to Azolla inoculation in model agronomic trials conducted, that the rice yields was very much higher from Azolla inoculated plots comparable to that of $60 \mathrm{~kg} \mathrm{~N} / \mathrm{ha}$. Such association is very much common in rice fields (Fig. 2).

\subsubsection{Mycorrhizae}

Mycorrhiza is the symbiotic association of fungus with roots of vascular plants. The main advantages of mycorrhiza to the host plants lies in the extension of the penetration zone of the root fungus system in the soil, facilitating an increased phosphorus uptake. Mycorrhizal fungi assist the uptake of phosphorus (Tinker, 1980) and trace metals and possibly influence water and nutrients via hormonal influences is not in doubt. Arbuscular Mycorrhizal (AM) fungi account for $5-50 \%$ of the biomass of soil microbes (Olsson et al., 1999). Biomass of hyphae of AM fungi may amount to $54-900 \mathrm{~kg} \mathrm{ha}^{-1}$ (Zhu and Miller, 2003) and some products formed by them may account for another $3000 \mathrm{~kg}$ (Lovelock et al., 2004). Pools of organic carbon such as glomalin produced by AM fungi may even exceed soil microbial biomass by a factor of 10-20 (Rillig et al., 2001).

\section{UTILIZATION OF GREEN MANURING CROPS IN ORGANIC FARMING}

\subsection{Green Manuring}

Green manuring is an essential component of tropical organic farming using green manures, often known as cover crops, are plants which are grown to improve the structure and nutrient content of the soil. They are a cheap alternative to artificial fertilizers and can be used alongside animal manures. Growing a green manure is not the same as simply growing a legume (nitrogen-fixing) crop, such as beans, in a rotation. Green manures are usually dug into the soil when the plants are still young, before they produce any crop and often before they flower. They are grown for their green leafy material which is high in nutrients and protects the soil. 
Table 2. Green manuring plants and their major nutrient content for organic agriculture

\begin{tabular}{|c|c|c|c|c|}
\hline \multirow[b]{2}{*}{ Nutrients (\%) } & \multicolumn{4}{|l|}{ Plants } \\
\hline & Artemisia vulgaris & Adhatoda vasica & Helianthus annus & Eupatorium adenophorum \\
\hline$\overline{\mathrm{N}_{2}}$ & 2.40 & 4.30 & 4.90 & 2.40 \\
\hline $\mathrm{P}_{2} \mathrm{O}_{5}$ & 0.45 & 0.90 & 0.85 & 0.70 \\
\hline $\mathrm{K}_{2} \mathrm{O}$ & 4.90 & 4.50 & 5.30 & -0.00 \\
\hline
\end{tabular}

Green manures are an ideal method of sustaining soil fertility in the tropics (Fageria, 2007) and in organic farming, for both soil fertility and microbial activity (Palm et al., 2001). Many studies in Asia (Katyal et al., 2001) highlight the value of green manures, although no studies report the benefits of ex situ or in situ application of the same material in comparison to that of only ex situ green manures on tropical upland crops. Green manuring is a practice of turning undecomposed green plant materials into the soil for improving the physical condition of soil or for adding nitrogen where the green manure crop is legume (Dhaliwal and Cheema, 1993). The process of green manure is of two types.

\subsubsection{Green Manuring in-situ}

A practice of turning undecomposed green manure crop into soil in the same field where the crop is grown (e.g., Sunhemp, Sesbania).

\subsubsection{Green Leaf Manuring}

This refers to turning of green leaves and tender green twigs collected from shrubs and trees grown on bunds, waste lands and hereby forest areas. The common shrubs and trees useful for this purpose are Glyricidia, Sesbabia.

\subsection{Advantages of Green Manuring}

- It adds organic matter to the soil

- The green manure crop return plant nutrients taken up by the crop from deeper layers, to the upper top soil

- It improves the structure of soil and other physical properties

- It facilitates penetration of rain water, thus decreasing run-off and erosion

- The green manuring crops hold plant nutrient that would otherwise be lost by leaching

- Leguminous plants add nitrogen to the soil

- It increases the availability of certain plant nutrients like phosphorus, calcium, potassium, magnesium and iron

The farmers are also using wild plants such as Titepati (Artemisia vulgaris), Siris (Albizzia lebbeck),
Daincha, sun-hemp, berseem, cowpea, lentil The used composition of some wild plants is given in the Table 2 .

\section{ORGANIC FARMING AND BIODIVERSITY}

Whether organic farming based agriculture enhances biodiversity has been a matter of research and debate in today's world (Norton et al., 2009). Extensive analyses suggest that organic farming is generally associated with higher levels of biodiversity with regards to both flora and fauna (Hawesa et al., 2010). Wide meta-analysis indicated that organic farming often has positive effects on species richness and abundance: 53 of the 63 studies analyzed (84\%) showed higher species richness in organic agriculture systems, but a range of effects considering different organism groups and landscapes. They proposed that positive effects of organic farming on species richness can be expected in intensively managed agricultural landscapes, but not in small-scale landscapes comprising many other biotopes as well as agricultural fields. Agriculturists confirm the positive effect of organic farming on biodiversity, but such benefits may be achieved also by conventional agriculture when carefully managed and indicate the need for long term, system-level studies of the biodiversity response to organic farming. Comparing local weed species diversity in organic and conventional agriculture in agricultural areas revealed that weed biodiversity was influenced by both landscape complexity and farming system. Local management (organic vs. conventional) and complexity of the surrounding landscape had an influence on alpha, beta and gamma diversities of weeds in agricultural fields. Species diversity under organic farming systems was clearly higher in simple landscapes, but conventional vegetation reached similar diversity levels when the surrounding landscape was richer because of the presence of refugia for weed populations. Agroenvironment schemes designed to preserve and enhance biodiversity should not only consider the management of single fields but also that of the surrounding landscape. Diversity and species composition of weed communities during spring in cereal fields cultivated by organic, conventional cereal and conventional dairy cropping 
reflect that organic cropping tends to promote weed species diversity at an early phase of cropping history, in particular for species susceptible to herbicides. A change in species composition would require a longer period of organic cropping. Thus organic systems tend to support a greater density, species number and diversity of weeds compared to conventional management. It has been demonstrated that when farming management is turned from conventional to organic, the weed populations can be restored to a state comparable to that before application of intensive cropping measures. However, the recovery of the weeds is reported to differ between species, with species with a more rapid recovery being nitrophilous species that suffered due to the application of herbicides, or species that were tolerant against herbicides. Perennial species favored by grasslands showed the slowest recovery. The application of diverse crop rotations in organic cropping is the focal factor affecting species composition of weed communities. Pfiffner et al. (2001) reported organic farming shows better performance in case of organism abundance and species diversity. The higher abundance might depend upon low-input and organic fertilization, more favorable plant biota protection management (especially weed management) and possibly upon closer interaction with semi-natural habitats. Organic farming increased both insect-pollinated as well as overall species richness, whereas the proportion of insect-pollinated plant species within the total species richness was unaffected by farming practices. It was found that number of arthropods, carabid species and earthworms were more abundant in organic than in conventional agroecosystems of different types of orchards and vineyards. In the largest and most comprehensive study of organic farming in UK to date, (Fuller et al., 2005) shows that organic farms provide greater benefits for a range of wildlife (including wild flowers, beetles, spiders, birds and bats) than their conventional counterparts. They found that organic fields were estimated to hold 68$105 \%$ more plant species and $74-153 \%$ greater abundance of weeds (measured as cover) than nonorganic fields support, 5-48\% more spiders in preharvest crops, $16-62 \%$ more birds in the first winter and $6-75 \%$ more bats. These studies indicate that organic farming systems provide greater potential for biodiversity as a result of greater variability in habitats and more wildlife-friendly management practices, which results in real biodiversity benefits, particularly for plants. Plants indeed showed far more consistent and pronounced responses to the use of organic systems when compared to other taxa. Such plant species richness was higher on farms with a heterogeneous landscape, while farming practice was of relatively less importance in relation to landscape features for species richness. Today's world economic pressure leads to an improvement in mechanical weed control and undersowing, supporting the fact that developing a diverse arable field flora cannot be done automatically just by converting to organic farming. Rather, integration with the guiding vision of organic agriculture is needed and measures to support the richness of species of arable field plants in organic fields have to be developed.

\section{CLIMATE CHANGE CHALLENGES FOR ORGANIC AGRICULTURE}

Organic agriculture avoids nutrient exploitation and increases soil organic matter content. In consequence, soils under organic agriculture capture and store more water than soils under conventional cultivation (Niggli et al., 2009). Production in organic agriculture systems is thus less prone to extreme weather conditions, such as drought, flooding and water logging. Organic agriculture accordingly addresses key consequences of climate change, namely increased occurrence of extreme weather events, increased water stress and drought and problems related to soil quality (IPCC, 2007a). Furthermore, organic agriculture reduces the vulnerability of the farmers to climate change and variability. First, it comprises highly diverse farming systems and thus increases the diversity of income sources and the flexibility to cope with adverse effects of climate change and variability, such as changed rainfall patterns. This leads to higher economic and ecological stability through optimized ecological balance and riskspreading. Second, organic agriculture is a low-risk farming strategy with reduced input costs and, therefore, lower risks with partial or total crop failure due to extreme weather events or changed conditions in the wake of climate change and variability (Scialabba and Hattam, 2002; Eyhorn, 2007). As such, it is a viable alternative for poor farmers. In addition, higher prices can be realized for the products via organic certification. Higher farm incomes are thus possible due to low input costs and high sale prices. The coping capacity of the farms is increased and the risk of indebtedness is lowered. Risk management, risk-reduction strategies and economic diversification to build resilience are also prominent aspects of adaptation.

Crops and crop varieties used in organic agriculture are usually well adapted to the local environment. Local effects of climate variability cannot be foreseen in detail because, on the local level, climate change models are not very accurate or even available. Adaptation thus may 
utilize measures that build on self-adaptive capacity, such as local crop-breeding. The systemic character (on farm breeding,) of such sustainable agricultural system is especially adequate to provide such. Notwithstanding this potential, more research is needed on how organic farming systems perform under increased disease and pest pressures, which are important effects of climate change on agriculture (IPCC, 2007a) and on how local crop varieties adapt to climate change and variability. Organic agriculture also seems to perform better than conventional agriculture under water constraints (Hepperly et al., 2006; Badgley et al., 2007).

By its nature, organic agriculture is an adaptation strategy that can be targeted at improving the livelihoods of rural populations and those part of societies that are especially vulnerable to the adverse effects of climate change and variability-for example, the rural population in sub-Saharan Africa; and improvements via reduced financial risk, reduced indebtedness and increased diversity (Eyhorn, 2007). By its systemic character, organic agriculture is an integrative approach to adaptation. Organic agriculture addresses many of the key challenges identified for adaptation to climate change and variability and it fulfills many of the criteria, which are seen as important general prerequisites for such strategies as described in (Slater et al., 2007; Prowse and Braunholtz-Speight, 2007; FAO, 2008). Organic agriculture as a mitigation strategy addresses both emissions avoidance and carbon sequestration. The first is achieved through:

- lower $\mathrm{N}_{2} \mathrm{O}$ emissions (due to lower nitrogen input)-it is usually assumed that $1-2 \%$ of the nitrogen applied to farming systems is emitted as $\mathrm{N}_{2} \mathrm{O}$, irrespective of the form of the nitrogen input. The default value currently used by the IPCC is $1.25 \%$, but newer research finds considerably lower values, such as for semi-arid areas (Barton et al., 2008)

- less $\mathrm{CO}_{2}$ emissions through erosion (due to better soil structure and more plant cover)-there usually is less erosion in organic farming systems than in conventional ones. The effect of erosion on $\mathrm{CO}_{2}$ emissions is still controversial (IPCC, 2007b)

- lower $\mathrm{CO}_{2}$ emissions from farming system inputs (pesticides and fertilizers produced using fossil fuel)

The effects of animal husbandry on mitigation in organic farming also need to be assessed. Animal manure is often of particular importance to organic farms, but livestock is also an important source of greenhouse gases (IPCC, 2007b). Soil carbon sequestration is enhanced through agricultural management practices (such as increased application of organic manures, use of intercrops and green manures, higher shares of perennial grasslands and trees or hedges), which promote greater soil organic matter (and thus soil organic carbon) content and improve soil structure (Niggli et al., 2009). Increasing soil organic carbon in agricultural systems has also been pointed out as an important mitigation option by (IPCC, 2007b). Very rough estimates for the global mitigation potential of organic agriculture amount to $3.5-4.8 \mathrm{Gt} \mathrm{CO}_{2}$ from carbon sequestration (around 55-80\% of total global greenhouse gas emissions from agriculture) and a reduction of $\mathrm{N}_{2} \mathrm{O}$ by two-thirds (Niggli et al., 2009). For sound estimates, however, more information on the mitigation potential of organic agriculture- duly differentiated according to climatic zones, local climatic conditions, soil characteristics, variations in crops and cultivation practices-is still needed.

\section{TRANSITION FROM CONVENTIONAL TO ORGANIC FARMING}

Farmers largely convert to organic farming because of the uneasiness experienced with the existing agriculture system, which is predominantly based on chemicals. Some farmers perceive chemical agriculture to be health hazard for themselves. However, personal health is not the only reason to convert to organic farming. Farmers are able to maintain their yield levels only through a drastic increase in chemical inputs. Yields in irrigated farms may go down during the conversion period from conventional to organic farming because the crop yields are boosted by artificial fertilizers and it takes time for the soil fertility to get boosted. However, after conversion, yields will be equal, if not higher compared to the yield during the conventional farming. In the rainfed farming, the situation is different; yields are significantly lower and thus, the difference in yields between the conventional and conversion period is narrow. Though comparative yield studies are only a few at both global and national levels, certain studies have provided a broad indication about the productivity of organic farms vis-à-vis conventional farms. Conversion from the traditional low-external input system of cultivation rarely results in lower yields. However, when switching from external-input-intensive forms of agriculture, the yields may decline significantly, atleast during the initial years of conversion, until the natural soil tilth and fertility are sufficiently restored. But, after 
that, they may stabilize at comparably, lower or even higher levels, depending on the efficiency of organic management and the quality of organic fertilizers applied (Das, 2007). The wide range of organic fertilizers that are based on local resources and farmers' knowledge (Butterworth et al., 2003) will take care of the manorial needs of farmers. Organic farming can compete economically with conventional farming when specific attention is given to optimum approaches while conversion. Information needs of organic farmers should be surveyed and information delivery systems should be tailored to meet those needs (Cacek and Linda, 1986).

In the case of crops like rice, organic cultivation appears to be less economical as compared to other crops. However there is more scope for minimizing the economic cost and environmental loss, under organic farming system in the long-run (Rajendran, 2002). Besides these, environmental balance is maintained such that crops, trees, animals and man can live more harmoniously. Reducing the use of pesticide can provide the growers with direct economic benefits by decreasing the cost of inputs, thereby increasing net returns (Brenner, 1991). Most organic farming practitioners have reported that it was not the premium price of the organic produce but the reduced expenditure on inputs and similar yields to their neighboring conventional farmers that motivated them towards organic farming (Sharma, 2005). Mader et al. (2002) have reported sustainable yields (though marginally reduced in some years) without agrochemicals in the temperate climatic conditions. On the other extreme, most agricultural scientists believe that without chemical fertilizers, large quantities of Farm Yard Manure (FYM) and other biomass material that will be needed to compensate for the fertilizers are also available. They believe that there are several crops that cannot produce high yields without the use of agrochemicals, fertilizers in particular and therefore, practicing organic farming means food insecurity for the country. Organic farmers need to borrow less money than conventional farmers for two reasons; firstly, organic farmers need to buy fewer inputs such as fertilizer and pesticides; and secondly, costs and income are more evenly distributed throughout the year on diversified organic farms. Organic farmers, however complain that they face discrimination by lenders, a possible economic disadvantage of organic farming. This problem is more perceived than real. Income and profitability of organic farms is equal or higher when compared to conventional and traditional farm. In the long run, organic farming offers more advantages compared to conventional farming, because it not only promises higher yields but also ensures higher yield security and reduces dependence on external inputs, thus making poor households less crisis-prone. These are weighty arguments, especially in the marginal locations (Julia et al., 2008).

\section{CASE STUDIES ON COTTON (GOSSYPIUM HIRSUTUM) and SOME LEGUMES}

Organic cotton or eco-cotton or green cotton is the cotton grown without inorganic fertilizers, pesticides and defoliants and duly certified by a recognized certifying organization. India has tremendous potential to emerge as a world leader in organic cotton (Venugopal et al., 1997). Indian cotton textile industry is one of the oldest organized enterprises and is supported by supply of raw cotton cultivated in the country. Cotton based products come to about $35 \%$ of the country's exports. The present level of cotton productivity is only about $300 \mathrm{~kg}$ lint/ha against a world average of $600 \mathrm{~kg}$. The low productivity is attributed to a large area under rain-fed farming-almost $65 \%$ of the cotton area. India has the largest area under cotton in the world, but it is only the third in terms of production. The productivity is low even after $75 \%$ of the cotton area is covered by the high yielding varieties. India needs to increase cotton production to meet both the domestic and international demand. This has to come from an increase in productivity, which is presently very low. The reason for low productivity among others is the diseases/pest attacks on the crop as a result of the conversion of the traditional varieties to the high yielding ones. India is the only producer of all the four species of cotton in the world. Not only this, the country produces the widest quality range of cotton suitable for spinning 6's to 12's count yarn which can meet the demand from both the domestic and international textile industries. During the first half of the last century, the country grew only the desi cotton and the American variety accounted for a small area only. The desi variety yields are low, but they require lesser moisture, resist pests and diseases to a considerable extent and are suitable in dry lands and this cotton was organically cultivated. The increasing demand for cotton pushed out the desi cotton from cultivation and was replaced by the high yielding varieties. The desi cotton is grown only on $25 \%$ of the total area under cotton at present. The conventional method of cultivation of cotton needs intensive production technologies requiring very high levels of inputs like fertilizers, insecticides and water for irrigation. The inputs are often excessively used causing 
ecological problems besides diminishing rate of returns. Use of pesticides in the cotton crop is very intense and several chemicals are used indiscriminately ignoring the environment. Even the chemicals, banned/restricted for use in the advanced countries, are used in the cotton crop. Organic cultivation of cotton under certification will be profitable as there is a strong demand for ecocotton in many Western and Asian countries. There are about 12 countries producing eco-cotton. USA, Greece, Israel, Peru, Egypt, Turkey, China and Australia are important eco-cotton producing countries. Eco-cotton commands a price higher than $30 \%$ to $40 \%$ of the conventional cotton. However, the cotton growers in the country will take up organic cultivation only if the yield loss if any, as a result of the switch over is compensated by high prices and the technology is feasible and financially viable. Organic cotton can be produced easily in those areas where cotton is raised under the dry farming conditions. These areas are under the desi variety and as such can be converted into organic cotton farming easily. High quality hand woven fabrics were made from desi cotton once upon a time. But white cotton has replaced the coloured ones during the last fifty years. Now there is a demand world over for organically produced coloured cotton and India is in a position to cater to the international market.

Leguminous plants, whether grown as pulses for grain, as pastures, in agroforestry or in natural ecosystems, provide the major Nitrogen $\left(\mathrm{N}_{2}\right)$ input into the biosphere as a result of their ability to convert atmospheric $\mathrm{N}_{2}$ to a form that can be assimilated by the plant. This ability arises because of mutually beneficial association (symbiosis) between the legume and soilborne, $\mathrm{N}_{2}$ fixing bacteria belonging to the genera Allorhizobium, Azorhizobium, Bradyrhizobium, Mesorhizobium, Rhizobium, Sinorhizobium, (widely referred as Rhizobium or rhizobia). Although $\mathrm{N}_{2}$ fixation is not restricted to this group of bacteria, but only the rhizobia provoke the formation of a novel $\mathrm{N}_{2}$ fixing organ: the nodule, on the roots and in some cases on the stems of their legume host plant. Legume nodules represent the most effective system for providing reduced nitrogen in agricultural production. Nodules are unusual in that they are formed as a result of the Rhizobium infecting the plant root, multiplying and fixing $\mathrm{N}_{2}$ to form ammonia within the plant cells. For their part, plants provide an environment conducive to sustained bacterial metabolism by reducing the internal free $\mathrm{O}_{2}$ level and providing the source of energy. In this way both symbiotic partners form a nutritionally complementary relationship. Nodulated legumes have the potential to provide the entire nitrogen requirement for their growth. In this way, they also influence the $\mathrm{N}$ balance of the soil and the availability of it to accompanying subsequent crops. By reducing inputs of nitrogen fertilizers, legumes reduce the cost of production and the potential for $\mathrm{N}$ contamination of water resources as well as producing, in the case of pulses, grain of high nutritional value (Hardarson and Atkins, 2003). The extent to which legumes fix $\mathrm{N}_{2}$ and factors that limit this activity are critical components in exploiting the utility of legumes in sustainable farming systems. Legume symbioses vary in their specificity (Broughton et al., 2000; Graham and Vance, 2000; Perret et al., 2000). Specificity involves recognition of the bacterium by the host and the host by the bacterium through the exchange of signal compounds, which induce differential gene expression in both partners. Consequently, diverse factors such as abiotic stresses (drought, salinity, water logging and temperature), inadequate soil fertility and unfavorable pH may affect these events have the potential to alter the pattern and frequency of nodulation as well as the subsequent level of $\mathrm{N}_{2}$ fixation. Furthermore, joint researches have shown that there is substantial variability for $\mathrm{N}_{2}$ fixation between legume species (Bliss and Hardarson, 1993) and also within species, between cultivars. One of the most successful "breeding for fixation" outcomes is the soybean program in Brazil (Alves et al., 2003), which as a result of continual evaluation of inoculated plants growing in now nitrogenous soils, has resulted in the development of lines that realize their full symbiotic potential. Mutant lines of soybean, pea, common bean and Lotus japonicus have also been generated that nodulate super abundantly (hyper-nodulation; Carroll et al., 1985). As single recessive gene controls the hyper- nodulation trait in soybean but despite potential utility, this gene has not been yet incorporated into commercial cultivars. The joint FAO/IAEA Programme to enhance $\mathrm{N}_{2}$ fixation by beans in Latin America (Bliss and Hardarson, 1993) as well as other programmes in the tropics and sub tropics of Asia (IAEA, 1998) have shown clearly that line with high $\mathrm{N}_{2}$ fixation can be identified in most important food legumes. Presumably these lines have been exploited to generate populations from which molecular markers for symbiotic traits might be identified and used in the Marker-Assisted Breeding (MAB) for screening for enhanced symbiotic properties.

\section{FURTHER RESEARCH NEEDED}

From these findings, it seems that further research would be beneficial in the following areas: 
- Quantification of the total biodiversity benefits of widespread organic farming (for example totaling the contribution of the in-field and field boundary biodiversity benefits)

- Assessment in different parts of the country of the biodiversity benefits of organic farms compared to the conventional farming regimes that are typical of the region (i.e., not using paired farms)

- The biodiversity benefits of organic farming in the uplands and also for the soil

- The impact of organic farming on aquatic ecosystems

- The diversity and biodiversity benefits of trees on organic farms

- The evolution of biodiversity levels on organic farms over time

- Organic farming and the sustainable management with proper nutritional food value requirements of designated conservation areas

- The cost efficiency in delivering biodiversity of different conservation measures

- The state and importance of agricultural genetic diversity

\section{CONCLUSION}

Agriculture remains the key sector for the economic development of most developing countries, because for development, any country should be self-sufficient for food shelter and cotton. To make a country selfsufficient, there has been intensive use of fertilizer for the last four decades, which has created several problems linking excessive fertilizer use with environment. Increased amount of nitrate in drinking water is due to excessive and improper use of nitrogen fertilizers, which is most important fertilizer related pollution issues. Nutrient enrichment, eutrophication of lakes and deterioration of surface water quality due to transportation of nutrients applied through fertilizer via leaching and runoff and sediment erosion are other problems. Contamination of soil by heavy metal through fertilizer, like cadmium from phosphatic fertilizer has been found to be carcinogenic is getting increasing attention of environmentalists. The significance of fertilizers in polluting the air is being viewed with concern after the course that nitrous oxide originating from agricultural soil can damage the ozone layer in the stratosphere. Agriculture is not sustainable if its resource base declines, or if it has an adverse impact on the environment or leads to economic hardship for farmers especially for farmers with limited resources and landless tenant cultivators. To overcome such problems, organic farming receives the top priority in sustainable agriculture. Experiments conducted on different legume crops grown under varying agro-ecological conditions proved the potentiality of bio-fertilizer and organic wastes as important source of plant nutrients. So, from the different reviewed study, it is clear that organic farming is practical proposition for sustainable agriculture if adequate attention is paid to this issue. There is urgent need to involve more and more scientists to identify the thrust area of research for the development of eco-friendly production technology.

\section{REFERENCES}

Alves, B.J.R., R.M. Boddey and S. Urquiaga, 2003. The success of BNF in soybean in Brazil. Plant Soil, 252: 1-9. DOI: 10.1023/A:1024191913296

Arora, C.L., V.K. Nayaar and S.S. Randhuwa, 1995. Note on secondary and micro nutrient content of fertilizers and manures. Ind. J. Agric. Sci., 45: 10-85.

Asmed, S., 1993. Agriculture-fertilizer interference in Asia. In: Issue of Growth and Sustainability, Asmed, S. (Ed.), Oxford and IBH Publishers, New Delhi, India.

Badgley, C., J. Moghtader, E. Quintero, E. Zakem and M. Chappell et al., 2007. Organic agriculture and the global food supply. Renew. Agric. Food Syst., 22: 86-108. DOI: $10.1017 / \mathrm{S} 1742170507001640$

Barton, L., R. Kiese, D. Gatter, K. Butterbach-Bahl and R. Buck et al., 2008. Nitrous oxide emissions from a cropped soil in a semi-arid climate. Global Change Biol., 14: 177-192. DOI: 10.1111/j.13652486.2007.01474.x

Bliss, F.A. and G. Hardarson, 1993. Enhancement of Biological Nitrogen Fixation of Common Bean in Latin America. 1st Edn., Kluwer, Dordrecht, Boston, London, ISBN-10: 079232451X, pp: pp: 160.

Brenner, L., 1991. Dollars an sense: The economic benefits of reducing pesticide use. J. Pesticide Reform, 11: 18-20.

Broughton, W.J., S. Jabbouri and X. Perret, 2000. Keys to symbiotic harmony. J. Bacteriol., 182: 5641-5652. DOI: $10.1128 /$ JB.182.20.5641-5652.2000

Butterworth, J., B. Adolph and B.S. Reddy, 2003. How Farmers Manage Soil Fertility: A Guide to Support Innovation and Livelihoods? 1st Edn., Natural Resources Institute, ISBN-10: 0859545547, pp: 80.

Cacek, T. and L.L. Linda, 1986. The economic implications of organic farming. Am. J. Alternative $\begin{array}{lll}\text { Agric., } & 1: & 25-29 .\end{array}$ $10.1017 / \mathrm{S} 0889189300000758$ 
Carroll, B.J., D.L. McNail and P.M. Grasshoff, 1985. A supernodulation and nitrate-tolerant symbiotic (nts) soybean mutant. Plant Physiol., 78: 34-40.

Carscy, R.J., R. Abaidoo, K. Dashiell and N. Sanginga, 1997. Effect of soybean on subsequent maize grain yield in the guinea savanna zone of West Africa. Afr. Crop Sci. J., 5: 31-38.

Chandrashekar, H.M., 2010. Changing scenario of organic farming in India: an overview. Int. NGO J., 5: 34-39.

Dahama, A.K., 2009. Organic Farming for Sustainable Agriculture. 2nd Edn., Agrobios, Jodhpur, ISBN-10: 8177540580, pp: 288.

Das, K., 2007. Towards a smoother transition to organic farming. Econ. Politic. Weekly, 42: 2243-2245.

Dhaliwal, D.K. and S. Cheema, 1993. Agronomy: Theory and Digest. 1st Edn., Kalyani Publishing, Ludhiana, pp: 274.

Dhaliwal, G.S. and O. Koul, 2010. Quest for Pest Management: From Green Revolution to Gene Revolution. 1st Edn., Kalyani Publishers, New Delhi, India, ISBN-10: 8127258709, pp: 386.

Eyhorn, F., 2007. Organic Farming for Sustainable Livelihoods in Developing Countries?: The Case of Cotton in India. 1st Edn., vdf Hochschulverlag AG, ISBN-10: 3728131113, pp: 223.

Fageria, N.K., 2007. Green manuring in crop production. J. Plant Nutr., 30: 691-719. DOI: 10.1080/01904160701289529

FAO, 2008. Climate change and food security: A framework document. FAO, Rome.

Fuller, R.J., L.R. Norton, R.E. Feber, P.J. Johnson and D.E. Chamberlain et al., 2005. Benefits of organic farming to biodiversity vary among taxa. Biol. Lett., 1: 431-434. DOI: 10.1098/rsbl.2005.0357

Graham, P.H. and C.P. Vance, 2000. Nitrogen fixation in perspective: An overview of research and extension needs. Field Crop Res., 65: 93-106. DOI: 10.1016/S0378-4290(99)00080-5

Hardarson, G. and C. Atkins, 2003. Optimizing biological $\mathrm{N}_{2}$ fixation by legumes in farming systems. Plant Soil, 252: 41-54. DOI: 10.1023/A:1024103818971

Hawesa, C., G.R. Squirea, P.D. Hallett, C.A. Watsonb and M. Young, 2010. Arable plant communities as indicators of farming practice. Agric. Ecosys. Environ., $\quad 138$ : 17-26. DOI: 10.1016/j.agee.2010.03.010
Hepperly, P., D. Douds Jr. and R. Seidel, 2006. The Rodale Farming Systems Trial (1981 to 2005): Long-Term Analysis of Organic and Conventional Maize and Soybean Cropping Systems. In: Long Term Field Experiments in Organic Farming, Raupp, J. (Ed.), International Society of Organic Agriculture Research, Berlin, ISBN-10: 3895745901, pp: 198.

IAEA, 1998. Improving Yield and Nitrogen Fixation of Grain Legumes in the Tropics and Sub-Tropics of Asia. 1st Edn., IAEA, Viena, pp: 149.

IFOAM, 2010. Organic food and farming: A system approach to meet the sustainability challenge. Kölling, A. (Ed.), Belgium, pp: 06-07.

IPCC, 2007a. Summary for policy makers. IPCC Fourth Assessment Report, Working Group II Report: Impacts, Adapt. Vulnerability.

IPCC, 2007b. Summary for policy makers. IPCC Fourth Assessment Report, Working Group III Report: Mitigation of Climate Change.

Julia, J., B. Willhelm and F. Schone, 2008. Organic farming: A contribution to sustainable poverty alleviation in developing countries? Reading Material on Organic Farming, DDS-Krishi Vigyan Kendra, Zaheerabad, Medak District Andhra Pradesh, India.

Karki, A.B. and J.B. Baral, 1977. Status of bio-fertilizer in Nepal: A review. J. Inst. Agric. Anim. Sci., 1: 155-169.

Katyal, J.C., N.H. Rao and M.N. Reddy, 2001. Critical aspects of organic matter management in the Tropics: The example of India. Nut. Cyc. Agroecosyst., 61: 77-88. DOI: 10.1023/A:1013320502810

Kostial, K., 1977. Cadmium. In: Trace Elements in Human and Animal Nutrition. Underwood, E.J. (Ed.), Academic Press, New York, ISBN-10: 0127090657.

Lovelock, C.E., S.F. Wright, D.A. Clark and R.W. Ruess, 2004. Soil stocks of glomalin produced by arbuscular mycorrhizal fungi across a tropical rain forest landscape. J. Ecol., 92: 278-287. DOI: 10.1111/j.0022-0477.2004.00855.x

Mader, P., A. Fliefback, D. Dubois, L. Gunst and P. Fried et al., 2002. Soil fertility and biodiversity in organic farming. Science, 296: 1694-1697. PMID: 12040197

Mahdi, S.S., G.I. Hassan, S.A. Samoon, H.A. Rather, S.A. Dar and B. Zehra, 2010. Bio-fertilizers in organic agriculture. J. Phytol., 2: 42-54. 
Niggli, U., A. Fliessbach, P. Hepperly and N. Scialabba, 2009. Low greenhouse gas agriculture: Mitigation and adaptation potential of sustainable farming systems. Rome.

Norton, L., P. Johnson, A. Joys and R. Stuart, 2009. Consequences of organic and non-organic farming practices for field, farm and landscape complexity. Agric. Ecosys. Env., 129: 221-227. DOI: 10.1016/j.agee.2008.09.002

Olsson, P.A., I. Thingstrup, I. Jakobsen and E. Baath, 1999. Estimation of the biomass of arbuscular mycorrhizal fungi in a linseed field. Soil Biol. Biochem., 31: 1879-1887. DOI: 10.1016/S00380717(99)00119-4

Palm, C.A., C.N. Gachengo, R.J. Delve, G. Cadish and K.E. Giller, 2001. Organic inputs for soil fertility management in tropical agro-ecosystems: Application of an organic resource base. Agric. Ecosyst. Environ., 83: 27-42.

Pandey, R.K. and S. Sharma, 1989. A Farmer's Primer on Growing Soybean on Riceland. 1st Edn., John Wiley and Sons, Incorporated, Manila, ISBN-10: 9780813814766, pp: 216.

Patel, N.T., S. Herbert and P.K. Parekh, 1982. Inputs Productivity in Agriculture: With an Emphasis on Irrigation and Farm Size. 1st Edn., Oxford and IBH New Delhi, pp: 226.

Perret, X., C. Staehelin and W.J. Broughton, 2000. Molecular basis of symbiotic promiscuity. Microbiol. Mol. Biol. Rev., 64: 180-201. PMID: 10704479

Pfiffner, L., A. Haring, S. Dabbert, M. Stolze and A. Piorr, 2001. Contributions of organic farming to a sustainable environment. Proceeding of Organic Food and Farming, Towards Partnership and Action in Europe, May 10-11, Copenhagen, Denmark, Dänish Ministry for Food, pp: 115-123.

Prowse, M. and T. Braunholtz-Speight, 2007. The first millennium development goal, agriculture and climate change. Overseas Development Institute.

Rajendran, S., 2002. Environment and economic dimensions of organic rice cultivation in South India. Porceedings of the International Conference on Asian Organic Agric, Nov. 12-15, Suwan, Korea,

Reddy, B.S., 2010. Organic farming: status, issues and prospects-A review. Agric. Econ. Res. Rev.

Rillig, M.C., S.F. Wright, K.A. Nichols, W.F. Schmidt and M.S. Torn, 2001. Large contribution of arbuscular mycorrhizal fungi to soil carbon pools in tropical forest soils. Plant Soil, 233: 167-177. DOI: 10.1023/A:1010364221169
Roger, P.A. and J.K. Ladha, 1992. Biological $\mathrm{N}_{2}$ fixation in wetland rice fields: Estimation and contribution to nitrogen balance. Plant Soil, 141: 41-50. DOI: 10.1007/BF00011309

Scaife, A. and M. Turner, 1983. Diagnosis of Mineral Disorders in Plants: Vegetables. 1st Edn., Her Majesty's Stationery Office, London, ISBN-10: 0112408044, pp: 95.

Scialabba, N.E. and C. Hattam, 2002. Organic Agriculture, Environment and Food Security. 4th Edn., Food and Agriculture Org., Rome, ISBN-10: 9251048193, pp: 252.

Sessitsch, A., J.G. Howieson, X. Perret, H. Antoun and E. Martinez-Romero, 2002. Advances in Rhizobium research. Critical Rev. Plant Sci., 21: 323-378. DOI: 10.1080/0735-260291044278

Sharma, A.K., 2004. Biofertilizers For Sustainable Agriculture. 1st Edn., Agrobios, India, pp: 407.

Sharma, S., 2005. Contour cultivation based natural farming technique. Organic Farming Newsletter, 1: 3-6.

Singh, C., 2003. Modern Techniques of Raising Field Crops. 2nd Edn., Oxford and IBH, New Delhi, ISBN-10: 812041599X, pp: 523.

Slater, R., L. Peskett, E. Ludi and D. Brown, 2007. Climate change, agricultural policy and poverty reduction: How much do we know. ODI Natural Resources Perspectives 109, London.

Stephens, J.H.G. and H.M. Rask, 2000. Inoculant production and formulation. Field Crops Res., 65: 249-258. DOI: 10.1016/S0378-4290(99)00090-8

Tinker, T., 1980. Agriculture and world development. Overseas Development Council, India, pp: 228-240.

Venkataramani, 1995. Role of bio fertilizer in organic farming: Organic farming in rainfed agriculture. Central institute for dry land agriculture, Hyderabad, India, pp: 85-95.

Venugopal, K., K. Natarajan, H.H. Khan and K. Ramamurthy, 1997. Eco-farming for sustainable cotton production in the dry tracts of India. Proceedings of International Conference on Ecological Agriculture: Towards Sustainable Development, Nov. 15-17, Chandigarh, India, pp: 589-599.

Willer, H. and L. Klicher, 2009. The world of organic agriculture: Statistics and emerging trends. IfOM, Bonn, FiBL, Frick, ITC, Geneva, Switzerland.

Zhu, Y.G. and R.M. Miller, 2003. Carbon cycling by arbuscular mycorrhizal fungi in soil-plant systems. Trends Plant Sci., 8: 407-409. DOI: 10.1016/S13601385(03)00184-5 